\title{
Comparative usefulness of PCR in the detection of Mycobacterium tuberculosis in different clinical specimens
}

\author{
MENG F. TAN, W. C. NG, S. H. CHAN* and WAN C. TAN \\ Departments of Medicine and *Microbiology, National University of Singapore, 10 Kent Ridge Road, \\ S(119260), Republic of Singapore
}

\begin{abstract}
The role of the polymerase chain reaction (PCR) in the diagnosis of tuberculosis in clinical practice remains to be defined; most results have been based on sputum samples. This study systematically compared the relative sensitivity and specificity of a single simplified method for different clinical samples. A wide range of clinical samples, including sputum, bronchoalveolar lavage fluid, cerebrospinal fluid, pleural fluid, gastric aspirate, pus and tissues (both fresh and paraffin-embedded) was tested. This method did not require routine DNA extraction before PCR, and consisted of an optimised single tube PCR amplification designed with different sets of time and temperature profiles. A total of 398 samples from 293 patients was studied. The sensitivity was $100 \%$ for all types of specimens, while the specificity ranged from $95 \%$ for sputum to $88 \%$ for bronchoalveolar lavage fluid and pleural fluid and to $85 \%$ for non-pulmonary specimens. This study showed that it was possible to employ a single simplified method with minor modifications for a wide range of specimens in clinical practice without loss of sensitivity and specificity.
\end{abstract}

\section{Introduction}

In recent years, the use of the polymerase chain reaction (PCR) for the amplification of DNA has appeared promising in terms of speed and direct application in clinical practice. Various PCR assays have been developed with different target templates for the rapid identification of Mycobacterium tuberculosis [1-9]. These methods differed in their DNA release technique $[8,10-12]$, the number of amplification cycles $[8,12,13]$, the use of nested amplification and re-amplification $[8,9,12-15]$ and the methods of detection $[6,12,16-18]$. The sensitivity and specificity of these methods were variable, ranging from $60 \%$ to $100 \%[15,16,19,20]$. Detection limits for suspensions of known isolates and clinical samples also varied from 1 to 1000 cells $[9,13,17]$.

Studies have shown that PCR assays with high sensitivities $(>90 \%)$ were associated with one or more of the following characteristics: (i) the use of nested amplification $[8,12]$; (ii) the use of reamplification [15]; (iii) the use of two $M$. tuberculosis-specific primer systems [21]; (iv) amplification of

Received 8 Feb. 1996; accepted 3 July 1996.

Corresponding author: Dr W. C. Tan. a repetitive sequence $[6,15]$; $(\mathrm{v})$ high percentage of acid-fast bacillus (AFB) smear-positivity in the clinical material [4-6, 8, 12-15]; (vi) low specificity $(<80 \%)$ $[2,5,21]$; and (vii) the routine use of a DNA extraction and purification procedure before amplification $[2,4,5,8,22]$. Furthermore, these reported assays were mostly tested with mycobacterial cultures or sputum specimens $[5,12,15,21,22]$. There is relatively little information on the usefulness of a standard PCR assay on different types of clinical specimens.

The aim of this study was to assess systematically the clinical applicability of a modified standard PCR assay for the rapid detection of $M$. tuberculosis in different clinical specimens. A simple and rapid sample preparation procedure that can be easily integrated into the routine schedule of a mycobacteriology laboratory was adopted. A PCR assay based on a repetitive sequence IS6110 [1, 23, 24] was used and the assay was optimised and simplified to a three-stage single-tube PCR amplification.

\section{Materials and methods}

Patients and specimens

In a prospective study, 398 clinical specimens were collected from 293 consecutive in-patients of two 
general hospitals in Singapore. The specimens were collected from patients under the following circumstances: (i) suspicion of active tuberculosis based on their clinical history and characteristic radiograph; (ii) a past history of tuberculosis; or (iii) a history of exposure to tuberculosis. The clinical specimens comprised sputum (236), bronchoalveolar lavage fluid (BALF, 47), pleural fluid (PF, 66), gastric aspirate (14), lymphoid tissue (7), cerebrospinal fluid (5), urine (6), lung aspirate (2), pus (5), bone marrow (3) and others (7). Bacteriological investigation and microscopy were performed by standard methods with LowensteinJensen egg media and Ziehl-Neelsen staining combined with light microscopy, respectively.

\section{Preparation of clinical specimens for PCR}

Sputum and other body fuids. Sputum was decontaminated according to the standard N-acetyl-L-cysteine$\mathrm{NaOH}$ method [12]. The sediments from sputum and other body fluids were resuspended in $200 \mu \mathrm{l}$ of $50 \mathrm{~mm}$ Tris- $\mathrm{HCl}$ containing $100 \mu \mathrm{l}$ of glass beads $(<106 \mu \mathrm{m}$, Sigma), boiled for $10 \mathrm{~min}$ and then disrupted in an ultrasonic water bath at $50^{\circ} \mathrm{C}$ (Branson Instrument Co., USA) for $15 \mathrm{~min}$ to release DNA [10].

Tissues. Tissues were minced, resuspended and incubated overnight in lysis buffer containing proteinase $\mathrm{K}$ (Sigma) $0.1 \mathrm{mg} / \mathrm{ml}$ at $37^{\circ} \mathrm{C}$ [4]. DNA was then extracted by the phenol:chloroform method followed by ethanol precipitation [8].

Specimens containing blood. As a first step before further processing, all blood-stained specimens (sputum and fluids) were repeatedly washed with lysis buffer [25] until clear.

\section{PCR protocol}

Two M. tuberculosis-specific oligonucleotide primers, IS1 and IS2 of the insertion element IS6110 were used for amplification [1]. The resulting PCR product is a 123-bp fragment. A third oligonucleotide probe, IS3, specific for the 123-bp fragment, was radiolabelled and used to confirm the sequence of the amplified DNA. Five $\mu \mathrm{l}$ of processed sample were added to $45 \mu \mathrm{l}$ of PCR buffer [26] containing $200 \mu \mathrm{M}$ (each) of dNTPs, $0.375 \mu \mathrm{M}$ each of two primers, 1 unit of sequencing grade Taq polymerase (Promega Corp., Madison, WI, USA). Amplification was performed with a modified and optimised three-stage protocol: (i) $94^{\circ} \mathrm{C}$ for $5 \mathrm{~min}$; (ii) 20 cycles of $30 \mathrm{~s}$ at $94^{\circ} \mathrm{C}, 40 \mathrm{~s}$ at $65^{\circ} \mathrm{C}, 30 \mathrm{~s}$ at $72^{\circ} \mathrm{C}$; and then (iii) 30 cycles of $60 \mathrm{~s}$ at $92^{\circ} \mathrm{C}, 40 \mathrm{~s}$ at $60^{\circ} \mathrm{C}, 60 \mathrm{~s}$ at $72^{\circ} \mathrm{C}[27]$ with an auto-extension of $5 \mathrm{~s}$ at $72^{\circ} \mathrm{C}$ at the end of each cycle.

\section{PCR controls}

Positive and negative controls were included in all PCR assays. Two types of positive control containing sequences complementary to the same set of primers were used: (a) MTB control containing a 123-bp DNA fragment amplified from DNA of a standard $M$. tuberculosis isolate; (b) HBV control (internal control) containing a 176-bp DNA fragment amplified from the serum of a patient infected with hepatitis $B$ virus.

\section{Detection and analysis of $P C R$ products}

Five $\mu 1$ of the PCR product were resolved electrophoretically on Nusieve agarose (FMC, Bioproduct, USA), $3.0 \%$ stained with ethidium bromide and visualised on a $312-\mathrm{nm}$ wavelength UV transilluminator. The amplified products were then transferred on to a nylon membrane and hybridised with radiolabelled oligonucleotide IS3 [28].

\section{Determination of PCR detection limits}

The DNA standard consisting of amplified $M$. tuberculosis DNA was first purified and then quantified by the GeneQuant machine (Phamacia, USA). The detection limit of the PCR assay in reagents and in clinical specimens were determined separately by amplification of serial dilutions of this standard with either water or clinical specimens previously tested as negative for $M$. tuberculosis DNA.

\section{Results}

Positive samples and positive $M$. tuberculosis controls produced DNA bands of $123 \mathrm{bp}$. All clinical samples that gave 123-bp fragments on ethidium bromidestained agarose gels were also positive by Southern hybridisation. The detection limit of the method in clinical samples was five mycobacterial cells. Inhibitors were found in $20(5 \%)$ of the 398 specimens. The majority of them were resolved by using a DNA extraction and purification procedure as described for the tissue specimens. Five specimens comprising four sputa and one pleural fluid from patients without mycobacterial infections, remained unresolved. In such instances, even the internal positive control was not amplified (Fig. 1).

Comparison of the final diagnoses with the results from bacteriological examination and PCR is shown in Table 1. Of 393 specimens, 125 were from patients in whom tuberculosis had been diagnosed; 12 samples were from patients with non-tuberculous mycobacterial disease; and 256 specimens were from patients without mycobacterial infection.

PCR gave positive results in all 125 specimens from 88 patients who were diagnosed clinically to have active tuberculosis (i.e., positive bacteriology or definite radiological evidence of active disease which resolved with antituberculous chemotherapy). Of these specimens, 46 were identified as microscopy- and 


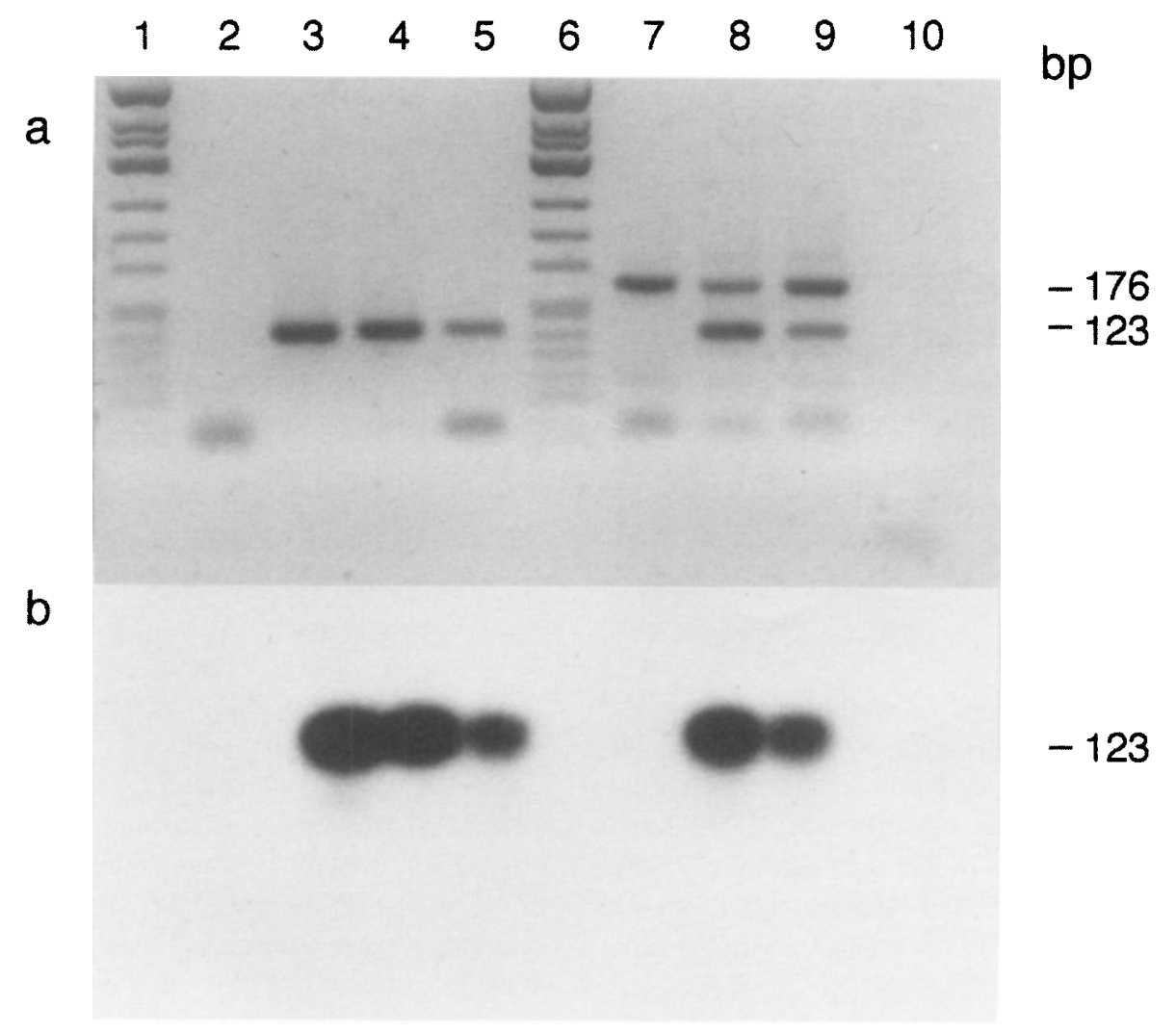

Fig. 1. Agarose gel electrophoresis (a) and Southern hybridisation (b) analysis of PCR-amplified DNA products. Lanes 1 and 6, $\varnothing \mathrm{X} 174$ Hinfl digest DNA mol. wt marker, 2, negative reagent control (no DNA); 3, MTB control; 4, microscopy-positive clinical sample; 5, microscopy-negative, culture-positive clinical sample; 7 , negative reagent control (with internal HBV control); 8, microscopy-positive clinical sample with internal control; 9, microscopynegative, culture-positive clinical sample with internal control; 10, clinical sample containing inhibitors of polymerase.

culture-positive; two were microscopy-positive and culture-negative; 67 were microscopy-negative and culture-positive; 10 were microscopy- and culturenegative. The sensitivities of microscopy, culture and PCR methods compared with clinical findings were
$38 \%$ (48 of 125$), 90 \%$ (113 of 125$)$ and $100 \%$ (125 of 125 ), respectively (Table 1$)$.

PCR gave negative results in all 12 specimens from six patients with known mycobacterial disease other

Table 1. Comparison of final diagnoses with the results from bacteriological examination and PCR

\begin{tabular}{|c|c|c|c|c|c|}
\hline \multirow[b]{2}{*}{ Final diagnosis } & \multirow{2}{*}{$\begin{array}{c}\text { Number of } \\
\text { patients }\end{array}$} & \multirow{2}{*}{$\begin{array}{l}\text { Number of } \\
\text { specimens }\end{array}$} & \multicolumn{3}{|c|}{ Number of specimens positive by } \\
\hline & & & microscopy & culture & PCR \\
\hline Tuberculosis* & 88 & 125 & 48 & 113 & 125 \\
\hline sputum & & 80 & 33 & 74 & 80 \\
\hline BALF & & 15 & 7 & 12 & 15 \\
\hline $\mathrm{PF}$ & & 16 & 1 & 15 & 16 \\
\hline non-pulmonary & & 14 & 7 & 12 & 14 \\
\hline \multicolumn{6}{|l|}{ Non-tuberculosis } \\
\hline mycobacterial infection & 6 & 12 & 12 & 12 & 0 \\
\hline sputum & & 10 & 10 & 10 & 0 \\
\hline BALF & & 0 & 0 & 0 & 0 \\
\hline PF & & 1 & 1 & 1 & 0 \\
\hline non-pulmonary & & 1 & 1 & 1 & 0 \\
\hline Non-mycobacterial disease & 194 & 256 & 0 & 0 & 22 \\
\hline sputum & & 142 & 0 & 0 & 7 \\
\hline BALF & & 32 & 0 & 0 & 4 \\
\hline $\mathrm{PF}$ & & 48 & 0 & 0 & 6 \\
\hline non-pulmonary & & 34 & 0 & 0 & 5 \\
\hline Sensitivity of & & & & & \\
\hline different methods & & & $38 \%$ & $90 \%$ & $100 \%$ \\
\hline
\end{tabular}

* The final diagnosis was based on culture results or definite clinical criteria. 
than tuberculosis (MOTT) namely, M. avium complex (1), M. avium-intracellulare complex (1), M. chelonei (5), M. kansasii (1) and M. scrofulaceum (4).

Of 256 specimens from 194 patients diagnosed clinically with non-mycobacterial diseases, PCR gave negative results in 234 specimens and positive results in 22 specimens giving an overall specificity of $91 \%$ (234 of 256). The 19 patients from whom the 22 specimens were obtained are under long-term surveillance for M. tuberculosis infection.

The comparative usefulness of PCR for prompt clinical diagnosis in different clinical specimens was defined by the ability of the assay to detect or to exclude tuberculosis in specimens from patients suspected of having tuberculosis when microscopy was negative. PCR was positive with all 80 sputum specimens from patients with tuberculosis while microscopy was positive in 33 specimens, giving sensitivities of $100 \%$ and $41 \%$, respectively. PCR was negative with 135 of 142 non-mycobacterial specimens, giving a specificity of $95 \%$. The details of other specimens are shown in Table 2. The sensitivity for the PCR assay was $100 \%$ for all specimens, while the specificities ranged from $95 \%$ for sputum to $85 \%$ for non-pulmonary specimens.

\section{Discussion}

This study showed that a simple PCR assay could be modified and applied to a wide range of clinical specimens, yielding consistently good results for sensitivity and specificity. A simple and environmentally safe DNA release method was adopted that required only boiling for $10 \mathrm{~min}$ and ultrasonication for $15 \mathrm{~min}$. The use of this simple DNA release method did not seem to impair the sensitivity of the PCR assay, which was $100 \%$. Hence, routine DNA extraction and purification were deemed unnecessary. This simple procedure could be easily integrated into the routine schedule of a mycobacteriology laboratory and required only the use of a general laboratory ultrasonic water bath.

The study also showed that good sensitivity and specificity were attainable with an optimised PCR assay such as the modified three-stage one-tube amplification. It was simple to perform and was subject to minimal risk of contamination [12]. The user needed only to deal with a single set of reagents and minimal pipetting.

Most reported assays used $M$. tuberculosis DNA as a positive control, necessitating a second reaction tube to test for inhibitory substances in the PCR-negative specimens to exclude false negative results. The present study demonstrated that it was possible to test for inhibitory substances within the same reaction tube by simply including an internal control in each amplification. Such a control was also described in three reported $M$. tuberculosis PCR assays [24, $29,30]$. The internal control used in the present assay had an additional advantage over the rest as it was simple to construct and was of a totally different nature from $M$. tuberculosis to ensure no crossreaction.

This study showed that an extra hybridisation procedure was not necessary in a routine test as all clinical specimens that gave positive results (123 bp) on ethidium bromide-stained agarose gel were also positive by hybridisation. All these simplifications greatly facilitate the integration of the modified threestage PCR assay into the routine schedule of a mycobacteriology laboratory.

A wide range of clinical specimens from both pulmonary and non-pulmonary sources was tested. Clinical correlation of the PCR results with that of the bacteriological and clinical findings showed 100\% sensitivity for all clinical specimens. Microscopy on the other hand was considerably less sensitive in detecting the majority of the positive specimens from clinically diagnosed cases, especially in the case of pleural fluid, for which it showed a sensitivity of only $6 \%$. The sensitivity of microscopy had been found to be highly variable in other studies $[5,16,19,22]$. There are three possible reasons. Firstly, microscopy could have failed to detect an initial low bacterial load in the test specimens, as a lower detection limit of $10^{4}$ micro-organisms $/ \mathrm{ml}$ of sample has been reported for this test $[3,4]$. Secondly, the staining method could

Table 2. The sensitivity and specificity of microscopy, culture and PCR for different clinical specimens when compared with the final diagnoses*

\begin{tabular}{|c|c|c|c|c|c|c|c|}
\hline \multirow{2}{*}{$\begin{array}{l}\text { Type of } \\
\text { specimen }\end{array}$} & \multirow{2}{*}{$\begin{array}{l}\text { Number of } \\
\text { specimens }\end{array}$} & \multicolumn{3}{|c|}{ Sensitivity $(\%)$ of } & \multicolumn{3}{|c|}{ Specificity $(\%)$ of } \\
\hline & & microscopy & culture & PCR & microscopy & culture & PCR \\
\hline Sputum & 236 & 41 & 93 & 100 & 77 & 100 & 95 \\
\hline BALF & 47 & 47 & 80 & 100 & 100 & 100 & 88 \\
\hline PF & 66 & 6 & 94 & 100 & 50 & 100 & 88 \\
\hline NP & 49 & 50 & 86 & 100 & 88 & 100 & 85 \\
\hline All & 398 & 38 & 90 & 100 & 80 & 100 & 91 \\
\hline
\end{tabular}

*Final diagnoses were based on culture results or definite clinical and radiological criteria. 
have influenced the sensitivity, as it is generally accepted that the flurochrome staining method is more sensitive than the Ziehl-Neelsen method that was used in this study $[5,19,31]$. Thirdly, it could also be due to differences in the technical expertise available in different routine service laboratories [19]. The low sensitivity of microscopy in many service laboratories further underscores the clinical relevance of the role of the PCR assay in the rapid detection of $M$. tuberculosis and its therapeutic impact.

The specificity of PCR ranged from $95 \%$ for sputum to $85 \%$ for non-pulmonary specimens. Lower values of specificity were observed with clinical specimens such as BALF, PF and NP. One paradoxical explanation was that PCR was very sensitive. PCR could have amplified $M$. tuberculosis DNA in samples where culture results were negative either because the organism was present in too few numbers to grow in culture or because host defences had rendered the mycobacteria non-cultivable. Nevertheless, the sensitivities and specificities of the method for all specimens are very comparable to the best figures reported for sputum in published reports $[5,12,15,21,22]$.

We conclude that a simple PCR assay with consistently high sensitivity and specificity could be applied to a wide range of clinical specimens. This optimised PCR assay would be easy to perform in a clinical mycobacteriology laboratory and hence may serve as a useful complement to clinical diagnosis.

We thank all patients and doctors who provided the samples for the studies. The study was supported by National University of Singapore grant RP920309.

\section{References}

1. Eisenach KD, Cave MD, Bates JH, Crawford JT. Polymerase chain reaction amplification of a repetitive DNA sequence specific for Mycobacterium tuberculosis. J Infect Dis 1990; 161: $977-981$

2. Pao CC, Yen TSB, You J-B, Maa J-S, Fiss EH, Chang C-H Detection and identification of Mycobacterium tuberculosis by DNA amplification. J Clin Microbiol 1990; 28: 18771880 .

3. Böddinghaus B, Rogall $\mathrm{T}$, Flohr $\mathrm{T}$, Blöcker $\mathrm{H}$, Böttger EC. Detection and identification of Mycobacteria by amplification of rRNA. J Clin Microbiol 1990; 28: 1751-1759.

4. Manjunath N, Shankar P, Rajan L, Bhargava A, Saluja S, Shriniwas. Evaluation of a polymerase chain reaction for the diagnosis of tuberculosis. Tubercle 1991; 72: 21-27.

5. Cousins DV, Wilton SD, Francis BR, Gow BL. Use of polymerase chain reaction for rapid diagnosis of tuberculosis. J Clin Microbiol 1992; 30: 255-258.

6. Kolk AHJ, Schuitema ARJ, Kuijper $\mathrm{S}$ et al. Detection of Mycobacterium tuberculosis in clinical samples by using polymerase chain reaction and a nonradioactive detection system. J Clin Microbiol 1992; 30: 2567-2575.

7. Soini H, Skurnik M, Liippo K, Tala E, Viljanen MK. Detection and identification of Mycobacteria by amplification of a segment of the gene coding for the 32-kilodalton protein. $J$ Clin Microbiol 1992; 30: 2025-2028.

8. Miyazaki Y, Koga H, Kohno S, Kaku M. Nested polymerase chain reaction for detection of Mycobacterium tuberculosis in clinical samples. J Clin Microbiol 1993; 31: 2228-2232.
9. Pierre C, Lecossier D, Boussougant $\mathrm{Y}$ et al. Use of a reamplification protocol improves sensitivity of detection of Mycobacterium tuberculosis in clinical samples by amplification of DNA. J Clin Microbiol 1991; 29: 712-717.

10. Buck GE, O'Hara LC, Summersgill JT. Rapid, simple method for treating clinical specimens containing Mycobacterium tuberculosis to remove DNA for polymerase chain reaction. $J$ Clin Microbiol 1992; 30: 1331-1334.

11. Liedtke W, Opalka B, Zimmermann CW, Schmid E. Different methods of sample preparation influence sensitivity of Mycobacterium tuberculosis and Borrelia burgdorferi PCR. PCR Methods Applic 1994; 3: 301-304.

12. Wilson SM, McNerney R, Nye PM, Godfrey-Faussett PD, Stoker NG, Voller A. Progress toward a simplified polymerase chain reaction and its applification to diagnosis of tuberculosis. $J$ Clin Microbiol 1993; 31: 776-782.

13. Pierre C, Olivier C, Lecossier D, Boussougant Y, Yeni P, Hance AJ. Diagnosis of primary tuberculosis in children by amplification and detection of mycobacterial DNA. Am Rev Respir Dis 1993; 147: 420-424.

14. Schluger NW, Kinney D, Harkin TJ, Rom WN. Clinical utility of the polymerase chain reaction in the diagnosis of infections due to Mycobacterium tuberculosis. Chest 1994; 105: $1116-1121$

15. Victor $T$, du Toit $R$, van Helden PD. Purification of sputum samples through sucrose improves detection of Mycobacterium tuberculosis by polymerase chain reaction. J Clin Microbiol 1992; 30: 1514-1517.

16. de Lassence A, Lecossier D, Pierre C, Cadranel J, Stern M, Hance AJ. Detection of mycobacterial DNA in pleural fluid from patients with tuberculous pleurisy by means of the polymerase chain reaction: comparison of two protocols. Thorax 1992; 47: 265-269.

17. Shawar RM, El-Zaatari FAK, Nataraj A, Clarridge JE. Detection of Mycobacterium tuberculosis in clinical samples by two-step polymerase chain reaction and nonisotopic hybridization methods. J Clin Microbiol 1993; 31: 61-65.

18. Sritharan V, Barker RH. A simple method for diagnosing $M$. tuberculosis infection in clinical samples using PCR. Mol Cell Probes 1991; 5: 385-395.

19. Clarridge JE, Shawar RM, Shinnick TM, Plikaytis BB. Large scale use of polymerase chain reaction for detection of Mycobacterium tuberculosis in a routine mycobacteriology laboratory. J Clin Microbiol 1993; 31: 2049-2056.

20. Noordhoek GT, Kolk AH, Bjune G et al. Sensitivity and specificity of PCR for detection of Mycobacterium tuberculosis: a blind comparison study among seven laboratories. $J$ Clin Microbiol 1994; 32: 277-284.

21. Beige J, Lokies J, Schaberg $\mathrm{T}$ et al. Clinical evaluation of a Mycobacterium tuberculosis PCR assay. J Clin Microbiol 1995; 33: $90-95$.

22. Yuen KY, Chan KS, Chan CM et al. Use of PCR in routine diagnosis of treated and untreated pulmonary tuberculosis. $J$ Clin Pathol 1993; 46: 318-322.

23. Thierry D, Cave MD, Eisenach KD et al. IS6110, an IS-like element of Mycobacterium tuberculosis complex. Nucleic Acids Res 1990; 18: 188.

24. Eisenach KD, Sifford MD, Cave MD, Bates JH, Crawford JT. Detection of Mycobacterium tuberculosis in sputum samples using a polymerase chain reaction. Am Rev Respir Dis 1991; 144: $1160-1163$.

25. Higuchi R. Simple and rapid preparation of samples for PCR. In: Erlich HA (ed) PCR technology - principles and applications for DNA amplification. New York, Stockton Press. 1989: $31-38$.

26. Ng WC, Guan R, Tan MF et al. Hepatitis C virus genotypes in Singapore and Indonesia. J Viral Hepat 1995; 2: 203-209.

27. Yap EPH, McGee JO'D. Short PCR product yields improved by lower denaturation temperatures. Nucleic Acids Res 1991; 19: 1713 .

28. Ford N, Nolan C, Ferguson M. Analysis and cloning of eukaryotic genomic DNA. In: Sambrook J, Fritsch EF, Maniatis T (eds) Molecular cloning: a laboratory manual, 2nd edn. Cold Spring Harbor, Cold Spring Harbor Laboratory Press. 1989: 45-46.

29. Kolk AHJ, Noordhoek GT, de Leeuw O, Kuijper S, van Embden JDA. Mycobacterium smegmatis strain for detection of Mycobacterium tuberculosis by PCR used as internal control for inhibition of amplification and for quantification of 
bacteria. J Clin Microbiol 1994; 32: 1354-1356.

30. deWit D, Wootton M, Allan B, Steyn L. Simple method for production of internal control DNA for Mycobacterium tuberculosis polymerase chain reaction assays. I Clin Microbiol
1993; 31: $2204-2207$.

31. Roberts GD, Thompson GP. Bacteriology and bacteriologic diagnosis of tuberculosis. In: David Schlossberg (ed) Tuberculosis. New York, Springer-Verlag. 1993: 55 